\title{
組合せ荷重を受けるプレートガーダーの極限強度 \\ ULTIMATE STRENGTH OF PLATE GIRDERS UNDER COMBINED BENDING AND SHEAR
}

\author{
小松定夫* - 森脇 良一** ・藤 野 真 之*** ・滝本哲四郎**** \\ By Sadao KOMATSU, Yoshikazu MORIWAKI, Masayuki FUJINO \\ and Tetsushiro TAKIMOTO
}

\section{1. まえがき}

プレートガーダーの腹板の座屈形式および枌の崩壊パ ターンは, せん断, 純曲げおよびせん断と曲げの組合せ の 3 通りの断面力を受ける場合に分類される ${ }^{1)}$. 一方, プレートガーダーが溶接で製作される場合, フランジや 腹板のような薄板構造要素には, 残留态力や初期たわみ などの初期不整が必然的に発生する.このような初期不 整が，上記 3 種類の座屈および崩壊パターンにそれぞれ 対応する腹板の座屈強度，および析全体の極限強度など の構造強度に，実際にどの程度の影響を与えるかについ て調查検討することが，プレートガーダーの設計の合理 化,さらに安全性を確保するために, 重要な課題として クローズアップされてきた.

ところで, プレートガーダーの設計としては, 古くか ら周知の弾性分岐座屈理論 ${ }^{2)}$ 基準とするものがある. ところが, 1957 年以降, Basler ${ }^{3) \sim 5) ~ な と ゙ に よ っ て, ~ い ~}$ わゆる腹板の局部座屈後における桁全体の力学的挙動が 詳細に研究されて以来, 多くの研究者によって, 腹板座 屈後の耐荷余力を重要視した桁全体の極限強度に関する 研究が盛んに行われるようになった，最近では，これら の研究成果を取り入れ，極限強度を基準にした設計が推 奨されている.

プレートガーダーの腹板の座屈強度および桁全体の極 限強度に関する理論的あるいは実験的研究は, せん断力 あるいは曲げモーメントが，それぞれ単独に作用する場 合については, きわめて多数の報告がなされている.し かしながら，プレートガーダーの座屈および崩壊挙動 は，せん断，曲げおよびこれらの組合せによる 3 つのパ

* 正会員 工博 大阪大学教授 工学部土木工学科

** 正会員 工博 (株) 神戸製鋼所構造研究所 次席研究員

*** 正会員 工博 (株) 神户製鋼所構造研究所 主任硎究員

**** 正会員 (株) 神巨製鋼所構造研究所 研究員
ターンに分類される.これらの各種パターンについて体 系的に検討した研究はきわめてわずかである.これに関 連して, Basler がおのおのの断面力を受ける場合につ いて, 腹板の座屈強度および析全体の極限強度を, 特定 の力学モデルを対象にして体系的に解析した. それ以 来, Ostapenko.Chern ${ }^{6) \sim 8)}$ が Basler の基本的な力学モ デルに枠組作用を加えて説明した．わが国においても， 秋田・藤井 ${ }^{91}$ (1) は曲げ座屈による忍力欠損状態を, より 忠実に実験結果に適合させ得るようなモデルを考案し， 塑性崩壊に立脚した上記 3 つのパターンに対する極限強 度式を提案した。さらに，Herzog ${ }^{12)}$ は，多くの実験結 果と Rockey•Skaloud ${ }^{13)}$ のモデル解析を併用することに より，簡便な実用公式を提案している.また，最近で

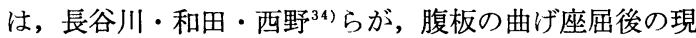
象を取り扱うため, 腹板の有効幅を取り上げて評価し， その有効幅と圧縮フランジからなる $\mathrm{T}$ 形断面を柱と考 え, 垂直補剛材位置を固定端とする崩壊モードを仮定し て，曲げ耐荷力を推定する 塑性解析理論を 発表してい る.このように, プレートガーダーの座屈, 極限強度に 関する研究の進展は顕著である.

一方, 初期不整と桁の極限強度の関係を論じた研究に ついては, 福本・藤原・渡辺 ${ }^{35)}$ が桁あるいははりの横倒 れ座屈に伴う極限強度について実験を行い, 残留応力が 極限強度に顕著に影響することを示したまた，長谷 川・西野・奥村 ${ }^{36), 37)}$ は, 水平補剛材を有する桁に曲げモ 一メントあるいはせん断力が単独に作用する場合の桁の 極限強度に及ぼす初期不整の影響について実験的に検討 し，初期たわみの極限強度への影響を論じた。また，文 献 37) では, 組合せ荷重下での実験結果より, 無補剛プ レートガーダーでの Basler の理論が水平補剛材を有す るプレートガーダーの極限強度算定に拡張できることを 論じた.これらの研究により, 初期不整と極限強度特性 の一面が明らかにされたが，この種の研究はいまだ数少 なく, 初期不整が必然的に発生する実橋のプレートガー 
ダーの設計を考えていくうえで, 種々の検討を加える余 地が残されているものと考えられる.

そこで, 著者らは, 実際の橋梁に多用される, 垂直補 剛材のみを有する基本的な単純支持された溶接プレート ガーダーを，わが国の材料，製作技術の現状に即して忠 実に再現した大型供試体を製作し，これによって，せん 断力と曲げモーメントを同時に受ける，いわゆる組合せ 荷重下での腹板の座屈強度, および析全体の極限強度が 初期不整によって実際にどのような影響を受けるかにつ いて, 文献 14) 17) で報告した一連の実験的研究によ って検討し, 実用的な強度経験式を提示した. しかし, これらの経験式は実験の範囲 (特に, $0.63 \leq \alpha \leq 2.0$, $4.5 \leq \psi \leq 11.4$, ただし $\alpha$ は腹板の綐横比， $\phi$ は $\beta$. $\sqrt{\sigma_{y w} / E}$ で与えられる腹板の幅厚比パラメーター, ここ に $\beta$ は腹板の幅厚比, $\sigma_{y w}$ は降伏点, $E$ は縦弾性係数) といら限られた範囲に対して適用可能であるが，このま までは一般性の面で問題がある.そこで, この適用範囲 をさらに拡張一般化するために，本論文では，桁全体の 極限強度解析を行おうとするものである.

プレートガーダーの極限強度解析は, 現在二つの方法 に大別される。一つは, 有限変位理論を適用して純理論 的に解析する方法であり, もら一つは, 適切な崩壊モー ドを設定し，その耐荷力を求めるいわゆる塑性解析法に より解析する方法である. 本報告での解析は, 曲げモー メントとせん断力が同時に作用する桁全体の力学モデル を考え, 各種崩壊パターンを想定し, そのときの極限強 度を塑性解析法により明らかにすることを目的としてい る. 極限強度の計算は荷重増分法により実施し, 各種因 子の影響を明らかにし, さらに著者らの 21 体の実験結 果 ${ }^{16}$ おおよび既報の 53 体の実験結果 (文献 18) 28)) と 本解析值を比較し, 解析法の妥当性を検証する.さら に, 著者らが提示した経験式 ${ }^{16), 17)}$ とこれら合計 74 体の 実験結果を比較し，経験式の適用範囲を明らかにしょう とするものである.

なお, 解析は次に示す条件および仮定のもとに実施し た.

(1) プレートガーダーの断面は I 形 1 軸対称断面とす る.

(2) 断面の曲げ剛性，そりねじれ剛性および St.Venant のねじれ剛性は弾性域のみ有効とする.

(3) 材料は, Mises の降伏条件に従う完全弾塑性体と し, 降伏後は初期降伏時の応力状態を保持するものとす る.

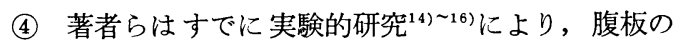
初期たわみが純曲げ座屈強度に与える影響を明らかにす るとともに, 桁全体の極限強度への影響がほとんどない ことを明らかにした，そこで, 本解析では, 腹板の初期

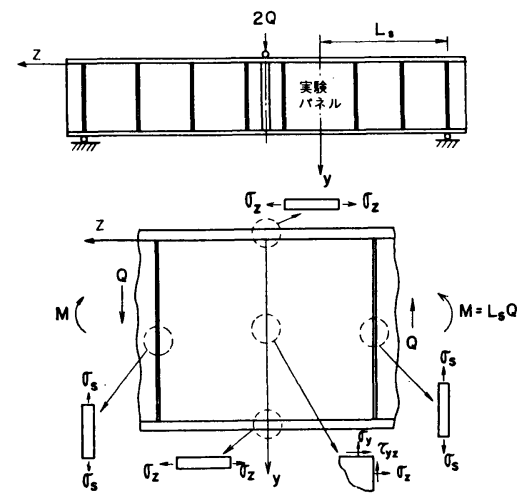

図一1 組合せ荷重下における作用応力と座標軸

たわみの影響を受けない，桁全体の極限強度を取り扱 5 .

(5) 桁断面の残留応力分布は, 既報 ${ }^{14), 29)}$ の基礎デー 夕を用いて定式化し，その大きさおよび分布形状は，腹 板座屈前後で変わらないものとする.

(6) 垂直補剛材は十分な剛性を有し，垂直補剛材の座 屈あるいは降伏に起因して桁が崩壊しないものとする.

(7) 応力については, 図一1 に示すように, フランジ では桁軸方向垂直応力のみを, 垂直補剛材では桁高方向 垂直応力のみを，腹板では桁軸方向と桁高方向の垂直応 力およびせん断応力を考慮し, 他の応力成分は考虑しな い.

(8) 実験パネル中央の断面に作用する曲げモーメント とせん断力を外力として導入する.

(9) プレートガーダーは静定系であると仮定し，した がって, 腹板の座屈あるいは局部降伏によって, 着目パ ネルの曲げモーメントとせん断力の比は変わらないもの とする.

(10) 着目パネルの曲げモーメントとせん断力の比を一 定に保持し, 両者が 0 から比例的に増加するものとす る.

\section{2. 解析方法}

\section{（1） 外力と応力成分の関係}

解析において最も重要なことは, 外力と断面内の応力 との関係をどのように考えるかである. 腹板の座屈が起 こるまでは, はり理論に従らと考えられるが, 腹板座屈 後の応力分布は複雑であり, 従来の研究者による国際的 討論の場においても統一的な結論に達していないようで ある゙、しかしながら，これまでの多くの実験的研究に よって, せん断力が支配的な場合については, 座屈後の 腹板には斜め方向の引張応力（斜張力）が生じ, このた 
め腹板座屈後も, なおかなりの耐荷余力が期待されるこ とが明らかとなっている. なお, 崩壊時には, 上下フラ ンジの曲げ剛性が小さい場合には，フランジのある位置 に塑性ヒンジが形成され得るとの報告(6),30) あり，既 報 ${ }^{14), 16)}$ の結果においても, 腹板の幅厚比, フランジの剛 度, フランジの垂直応力分布により, その形成の認めら れたものあるいは認められないものの両者のケースがあ った. そこで, 本論文ではこのような枠組作用による耐 荷力も考慮する. 一方, 曲げモーメントを支配的に受け る場合には, 腹板座屈後 の圧縮側腹板には忘力を 受け持たない部分が生 じ, 圧縮側の軸力は, こ の部分を除いた圧縮側の 腹板部分 (腹板の有效幅) と圧縮フランジとからな る $\mathrm{T}$ 断面 (図一2) に受 け持たれる傾向のあるこ

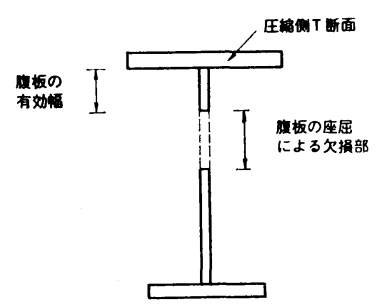

図-2 腹板座屈後の圧縮側 T 断面 とが既報 ${ }^{15)}$ の実験的研究でも明らかにされた. また，こ のような現象のあることは，文献 4)，7，10，31）でも 報告されている. また, その崩壊モードに関しては, 桁 全体が下フランジを中心にねじれ，かつ横方向に変形す る水平座屈と, 圧縮フランジと腹板の一部からなる $\mathrm{T}$ 断 面部分が, 圧縮フランジの中心まわりに局部的なねじれ を生ずるモード ( $\mathrm{T}$ 断面のねじれ座屈), 圧縮フランジ が局部的に垂直方向に変形するモード（垂直座屈）の 3 種類が存在すると報告 ${ }^{4)}$,7)されている. また, 先述した 文献 34) では，T断面部分の柱の座屈をプレートガーダ 一の曲げ而荷力に結びつけた理論が展開されており, 設 計に対する一つの考え方が示されている.

既報 ${ }^{16)}$ の実験的研究によれば, せん断力と曲げモーメ ントを同時に受ける場合も, 類似の現象（せん断力が支 配的な場合は斜張力が生じ, 曲げモーメントが支配的な
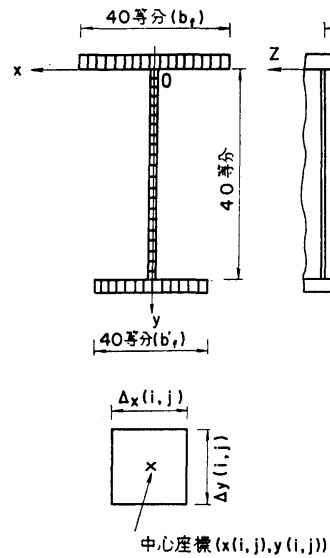

図一3 座標軸と要素分割
場合は，圧縮側腹板に断面欠損部が生ずる現象）が認め られた. そこで, これらの実験結果を十分尊重して, 腹 板座屈前後の外力と応力の関係を以下の (b) および (c) に述べるように考察した. なお，本解析は荷重増分法に 基づいており, 外力と応力の関係は増分関係で与えてい る. 解析では, 図-3 に示すように実験パネルの中央断 面における圧縮フランジの下縁と腹板との接合点に座標 原点 $\mathrm{O}$ をり $, x, y, z$ の各座標軸を設定した.また, 降伏域の広がりの評価を容易にするために, I 断面を 120 の要素（圧縮フランジ 40 等分, 腹板 40 等分, 引張 フランジ 40 等分) に細分割した.

\section{a) 断面諸量の計算}

解析に必要な断面諸量は, 次のように算定した。な お，以下の式においては 図一3 に示す要素番号の添字 $(i, j)$ は，特別な場合を除いて省略する.

(1) 要素に関する断面諸量

断面積 : $\Delta A=\Delta x \cdot \Delta y$

要素中央を通り $x$ 軸に平行な軸まわりの断面 2 次モー

$$
\text { メント: } \Delta I_{x}=\Delta x \cdot(\Delta y)^{3} / 12
$$

要素中央を通り $y$ 軸に平行な軸まわりの断面 2 次モー

$$
\text { メント : } \Delta I_{y}=\Delta y \cdot(\Delta x)^{3} / 12 \cdots
$$

(2) I 断面に関する断面諸量

断面積 : $A=\$ \Delta A$

ただし，は全要素の和を示す.

弾性断面積 : ${ }_{e} A=\sum \Delta A$

ただし， $\sum$ は弾性要素の和を示す.

弾性断面の図心の $y$ 座標 :

$$
{ }_{e} y_{c}=\sum(\Delta A \cdot y) /{ }_{e} A
$$

弾性断面の図心を通り $x$ 軸に平行な軸まわりの断面 2 次モーメント：

$$
{ }_{e} I_{x}=\sum\left(\Delta A \cdot y^{2}\right)-{ }_{e} y_{c}{ }^{2} \cdot{ }_{e} A+\sum \Delta I_{x}
$$

弾性断面の $y$ 軸まわりの断面 2 次モーメント：

$$
e^{I_{y}}=\sum\left(\Delta A \cdot x^{2}\right)+\sum \Delta I_{y}
$$

弾性断面のそりねじれ定数 :

$$
e^{I_{w}}=\frac{\sum_{i=1}\left(\Delta A \cdot x^{2}\right) \cdot \sum_{i=3}\left(\Delta A \cdot x^{2}\right) \cdot\left(d_{w}+t_{f} / 2+t_{f}^{\prime} / 2\right)^{2}}{\sum_{i=1}\left(\Delta A \cdot x^{2}\right)+\sum_{i=3}\left(\Delta A \cdot x^{2}\right)}
$$

弾性断面のせん断中心の $y$ 座標 :

$$
{ }_{e} y_{s}=\sum\left\{\Delta A \cdot x^{2}\left(y-e_{e} y_{c}\right)\right\} /{ }_{e} I_{y}+{ }_{e} y_{c}
$$

弾性断面の St. Venant のねじれ定数 :

$$
{ }_{e} K_{T}=\left\{t_{f^{2}} \sum_{i=1} \Delta A+t_{w}{ }^{2} \sum_{i=2} \Delta A+t_{f}^{\prime 2} \sum_{i=3} \Delta A\right\} / 3
$$

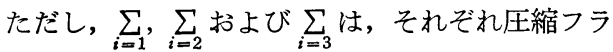
ンジ，腹板および引張フランジのみの弾性要素の和 を示寸. また, $d_{w}$ は腹板高, $t_{f}, t_{w}$ および $t_{f}{ }^{\prime}$ は, それぞれ圧縮フランジ厚, 腹板厚および引張フラン 
ジ厚を示す.

(3) 圧縮側の $\mathrm{T}$ 断面に関する断面諸量（腹板座屈後， 圧縮側の腹板に軸力を受け持たない 部分が生じ, 図一2 に示すように断面欠損部が生じるが，この断面欠損部を 除いた圧縮側 T断面をいら)

弾性断面の $y$ 軸まわりの断面 2 次モーメント：

$$
e^{I_{y T}}=T \sum\left(\Delta A \cdot x^{2}\right)+T \sum \Delta I_{y}
$$

ただし， $T \sum$ は圧縮側 $T$ 断面に含まれる弾性要

\section{素の和を示す.}

弾性断面のそりねじれ定数 : ${ }_{e} I_{w T}=0$

弾性断面の St. Venant のねじれ定数 :

$$
{ }_{e} K_{T T}=\left\{t_{f}{ }^{2} \cdot T \sum_{i=1} \Delta A+t_{w}{ }^{2} \cdot T \sum_{i=2} \Delta A\right\} / 3
$$

弾性断面のせん断中心の $y$ 座標 :

$$
e y_{s T}=-t_{f} / 2 \text {. }
$$

(4) 有効曲げ断面に関する断面諸量（図一2 に示す断 面欠損部を I 断面から除いた残りの断面）

弾性断面の図心の $y$ 座標 :

$$
{ }_{e} y_{C M}={ }_{M} \sum(\Delta A \cdot y) /_{M} \sum \Delta A
$$

ただし， $M \sum$ は有効曲げ断面に含まれる弾性要素

の和を示す.

弾性断面の図心を通り $x$ 軸に平行な軸まわりの断面 2 次モーメント：

$$
{ }_{e} I_{x M}={ }_{M} \sum\left(\Delta A \cdot y^{2}\right)-{ }_{e} y_{C M}{ }^{2} \cdot{ }_{M} \sum \Delta A+{ }_{M} \sum \Delta I_{x}
$$

\section{b）腹板座屈前の外力と応力の関係}

せん断力の増分 $(\Delta Q)$ に対しては, 薄い腹板の弾性断 面にほぼ一様なせん断応力の増分 $\left(\Delta \tau_{y z}\right)$ が生じてつり 合い, 曲げモーメントの増分 $(\Delta M)$ に対しては, 桁の 弾性断面に図心からの距離に比例する $z$ 方向の垂直応力 の増分 $\left(\Delta \sigma_{z}\right)$ が生じてつり合らことから, 次式が成立 する・

$$
\begin{aligned}
& \Delta \tau_{y z}=\Delta Q / \sum_{i=2} \Delta A \cdots \cdots . \\
& \Delta \sigma_{z}=\Delta M\left(y-{ }_{e} y_{c}\right) / I_{e}
\end{aligned}
$$

また, その他の応力増分はないものとし, それぞれ腹 板と垂直補剛材の $y$ 軸方向の垂直応力増分 $\Delta \sigma_{y}$ と $\Delta \sigma_{s}$ は 0 とする.

c）腹板座屈後の外力と応力の関係

ある腹板パネルのみがせん断座屈を生じ張力場が発生 したものとする. その腹板のせん断力の増分 $(\Delta Q)$ に対 しては, 腹板の弾性断面に生ずる斜張力増分 $\left(\Delta \sigma_{t}\right)$ の $y$ 軸, $z$ 軸方向の成分と直交座標方向の応力成分の増分 $\left(\Delta \tau_{y z}\right.$ および $\left.\Delta \sigma_{y}\right)$ とのつり合い, 曲げモーメントの増 分 $(\Delta M)$ に対しては，有効曲げ断面の弾性断面の図心 からの距離に比例する $z$ 軸方向の応力増分 $\left(\Delta \sigma_{z m}\right)$ とつ り合うことから，次のような関係が導かれる.

まず, 腹板の分割要素に生ずる単位幅当たりの斜張力
の増分を $\rho \cdot \Delta \sigma_{t}$ とし， 図一4に示すように, $y$ と $z$ の值交 2 軸方向の 応力成分の増分 $\left(\Delta \tau_{y z}\right.$, $\left.\Delta \sigma_{y}, \Delta \sigma_{z t_{2}}\right)$ とのつり合 いを考えると，次式が得 られる。

$$
\begin{gathered}
\Delta \tau_{y z}=\rho \cdot \Delta \sigma_{t} \\
(\sin 2 \phi) / 2 \cdots(20) \\
\Delta \sigma_{y}=\rho \cdot \Delta \sigma_{t} \cdot \\
(1-\cos 2 \phi) / 2 \\
\cdots \cdots \cdots \cdots(21) \\
\Delta \sigma_{z t 2}=\rho \cdot \Delta \sigma_{t} \cdot \\
(1+\cos 2 \phi) / 2
\end{gathered}
$$

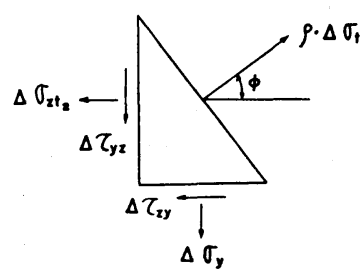

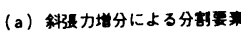
の2 軸方向成分

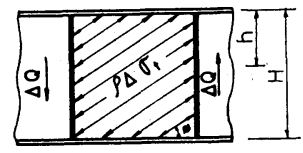

(b) 鈄强力とせん断力の闑保

図一4 斜張力モデル
ただし, $\rho$ は斜張力の平均化係数であり，その求め方は

3. で述べる.

次に, せん断力の増分とのつり合い式 $\left(\Delta Q=\sum \Delta \tau_{y z}\right.$. $\Delta A ）$ と式 (20) より，次式が得られる.

$$
\Delta \sigma_{t}=\Delta Q /\left\{\sin \phi \cdot \cos \phi \sum_{i=2}(\rho \cdot \Delta A)\right\}
$$

また，斜張力が垂直補剛材を通して圧縮および引張う ランジに作用し，両フランジには桁軸方向の圧縮応力 $\left(\Delta \sigma_{z t_{1}}, \Delta \sigma_{z t 3}\right)$ が発生する.これらの軸力が斜張力の $z$ 方向成分 $\left(\sum_{i=2} \Delta \sigma_{z t 2} \cdot \Delta A\right)$ と垂直補剛材を介してつり合う ことから, 以下のように $\Delta \sigma_{z t_{1}}, \Delta \sigma_{z t_{3}}$ が与えられる.

$$
\begin{array}{r}
\Delta \sigma_{z t_{1}}=(K-1) \cdot \Delta \sigma_{t} \cdot(1+\cos 2 \phi) \cdot \sum_{i=2}(\rho \cdot \Delta A) /\left(2 \sum_{i=1} \Delta A\right) \\
\ldots \ldots \ldots \ldots \cdots \cdots \cdots \cdots \cdots \cdots \cdots \cdots \cdots \cdots \cdots \cdots \cdots \cdots \cdots \cdots \cdots \cdots \cdots \cdots \\
\Delta \sigma_{z t_{3}}=-K \cdot \Delta \sigma_{t} \cdot(1+\cos 2 \phi) \cdot \sum_{i=2}(\rho \cdot \Delta A) /\left(2 \sum_{i=3} \Delta A\right)
\end{array}
$$

ただし, $K=h / H$ であり, $h$ は斜張力の合力の腹板にお ける作用中心点と圧縮フランジの中心との間隔であり, $H$ は圧縮フランジ中心と引涱フランジ中心との間隔で ある. 1 次モーメントのつり合い式, $\sum_{i=2}\left(\sigma_{z t 2} \cdot y \cdot \Delta A\right)=$ $\left(h-t_{f} / 2\right) \sum_{i=2}\left(\sigma_{z t_{2}} \cdot \Delta A\right)$ より $h$ が求まる. すなわち, $K$ は次式で与えられる.

$$
K=\frac{\sum_{i=2}(\rho \cdot \Delta A \cdot y) / \sum_{i=2}(\rho \cdot \Delta A)+t_{f} / 2}{d_{w}+t_{f} / 2+t_{f}^{\prime} / 2}
$$

次に, 斜張力による $z$ 方向の応力成分と垂直補剛材の 圧縮軸力がつり合ら条件より, 同様にして求めると, 重 直補剛材の応力増分 $\left(\Delta \sigma_{s}\right)$ は次式の上うになる.

$$
\Delta \sigma_{s}=\alpha \cdot \Delta \sigma_{t} \cdot(1-\cos 2 \phi) \cdot \sum_{i=2}(\rho \cdot \Delta A) /\left(2 A_{s}\right)
$$

ただし， $A_{s}$ は垂直補剛材の断面積である.

一方, 曲げモーメントの増分 $(\Delta M)$ によって, 有効 曲げ断面に生ずる軸応力増分 $\left(\Delta \sigma_{z m}\right)$ は次式で与えられ る. 


$$
\Delta \sigma_{z m}=\left.\Delta M \cdot\left(y-{ }_{e} y_{c M}\right)\right|_{e} I_{x M} \cdot
$$

ここに ${ }_{e} I_{x M}$ は，応力欠損部および塑性領域を除く断面 部分の図心に関する断面 2 次モーメントである.

そこで, 組合せ荷重下での腹板座屈後の $z$ 軸方向の応 力増分 $\left(\Delta \sigma_{z}\right)$ は, 圧縮フランジでは式 (24) と式 (28) を重ね合わせたもので与えられ, 腹板および引張フラン ジでも同様に求まり，それぞれ次式で与えられる.

$$
\left.\begin{array}{l}
\left.\Delta \sigma_{z}=\Delta \sigma_{z t_{1}}+\Delta \sigma_{z m} \quad \text { (圧縮フランジ }\right) \\
\Delta \sigma_{z}=\Delta \sigma_{z t_{2}}+\Delta \sigma_{z m} \text { (腹板) } \\
\left.\Delta \sigma_{z}=\Delta \sigma_{z t_{3}}+\Delta \sigma_{z m} \text { (引張フランジ }\right)
\end{array}\right\}
$$

以上のように求められた腹板座屈後の外力と応力の関 係は, 曲げモーメントとせん断力の比が一定であるとい う仮定を考慮すれば, 要素の各応力成分の増分とせん断 力の増分との間に線形関係が成立していることを示して いる.この関係が成立するためには, 外力の一つの増分 区間の中では, 桁の弾性断面に変化のないことが条件と なる. その意味から, 外力の増分量の決定は, 本解析に おいて重要な項目の一つであり, その決定法を以下に述 べる.

いま, ある外力 $(P)$ において, 弾性状態にある一つ の要素に着目し, その要素の応力成分を一般に $\sigma_{x}, \sigma_{y}$, $\sigma_{z}, \tau_{x y}, \tau_{y z}, \tau_{z x}$ であるとする.また，与えられた外 力の増分と态力の増分との線形関係から, 外力の小さい 増分 $\left(\Delta P_{0}\right)$ に対する応力の増分が $\Delta \sigma_{x}, \Delta \sigma_{y}, \Delta \sigma_{z}, \Delta \tau_{x y}$, $\Delta \tau_{y z}, \Delta \tau_{z x}$ であるとする. この要素を降伏させるに必 要な外力の増分を $\Delta P_{0}$ の $r$ 倍だとすると, 平面応力状 態における Mises の降伏条件によって次式が成立する.

$$
\begin{aligned}
& \left(\sigma_{y}+r \cdot \Delta \sigma_{y}-\sigma_{z}-r \cdot \Delta \sigma_{z}\right)^{2}+\left(\sigma_{z}+r \cdot \Delta \sigma_{z}\right)^{2} \\
& \quad+\left(-\sigma_{y}-r \cdot \Delta \sigma_{y}\right)^{2}+6\left(\tau_{y z}+r \cdot \Delta \tau_{y z}\right)^{2}=2 \sigma_{Y}{ }^{2}
\end{aligned}
$$

ここに, $\sigma_{Y}$ は 1 軸引張降伏応力度である. 式 (30) は $r$ に関する 2 次方程式となり, 容易に正根が求められ る.また，他のすべての弾性要素についても式 (30) と 同様に $r$ 正根が得られ，それらのらちで最小のものを $r^{*}$ とすると, $r^{*} \cdot \Delta P_{0}$ が求める外力の増分量である.こ のようにして外力の増分量を決定すれば，その増分区間 では析断面における弾性断面に降伏域が生ぜず，したが って, 外力の増分と応力の増分との間に線形関係が成立 することになる.

\section{（2）腹板の座屈強度および析全体の極限強度}

プレートガーダーは外力の増加に伴って, 腹板の坐屈 および析全体の崩壊を起こすが，本解析では，これらの 構造強度の計算を以下のように実施した.

\section{a) 腹板の座屈強度}

曲げモーメントとせん断力を同時に受ける板の座屈強 度は, E. Chwalla ${ }^{32)}$ などによって求められている. 本
解析では，この理論式を活用することにし，次式に示 す.

$$
\frac{1+C}{2}\left(\frac{\sigma_{c r}}{\sigma_{c r 0}}\right)+\frac{1-C}{2}\left(\frac{\sigma_{c r}}{\sigma_{c r 0}}\right)^{2}+\left(\frac{\tau_{c r}}{\tau_{c r 0}}\right)^{2}=1
$$

ここに, $C$ は圧縮縁応力度 $\sigma_{C}$ と引張縁応力度 $\sigma_{T}$ の比 $\left(\sigma_{T} / \sigma_{C}\right)$ を示し， $\sigma_{c r 0}, \tau_{c r 0}$ はそれぞれ純曲げ座屈応力 度, 純せん断座屈応力度, $\sigma_{c r}, \tau_{c r}$ はそれぞれ組合せ荷 重下で座屈するときに共存する曲げ座屈応力度, および せん断座屈応力度であり, それぞれ次式で与えられる.

$$
\left.\begin{array}{l}
\sigma_{c r 0}=k_{b} \cdot \sigma_{e}, \quad \tau_{c r 0}=k_{s} \cdot \sigma_{e} \\
\sigma_{c r}=k_{b c} \cdot \sigma_{e}, \quad \tau_{c r}=k_{s c} \cdot \sigma_{e}
\end{array}\right\} \ldots . . .
$$

ここに, $E$ は縦弾性係数, $\mu$ はポアソン比を示す. $k_{b}$, $k_{s}$ はそれぞれ板の純曲げ弹性座屈係数, 純せん断弾性 座屈倸数であり，それぞれ次式で与えられる.

(1) 周辺単純支持の場合

$$
\begin{aligned}
& k_{b}=-0.26 C^{3}+6.14 C^{2}-9.69 C+7.81 \\
& k_{s}=5.34+4 / \alpha^{2} \quad(\alpha \geq 1) \\
& k_{s}=5.34 / \alpha^{2}+4 \quad(\alpha<1)
\end{aligned}
$$

(2) 非載荷辺固定，載荷辺単純支持の場合

$$
\left.\begin{array}{l}
k_{b}=3.38 C^{3}+13.32 C^{2}-15.64 C+13.54 \\
k_{s}=8.98+6.18 / \alpha^{2}-2.88 / \alpha^{3} \quad(\alpha \geq 1) \\
k_{s}=14.1 \alpha-13.71+6.55 / \alpha+5.34 / \alpha^{2} \quad(\alpha<1)
\end{array}\right\}
$$

これらの式より, 組合せ荷重下で腹板が座屈するとき に共存する弾性座屈せん断力 $\left(Q_{c r}\right)$ は次に示す $k_{s c}$ よ り算定される.

$$
k_{s c}=\frac{\begin{array}{c}
-(1+C) k_{s}{ }^{2} \cdot k_{b} \cdot \eta+\left\{16 k_{s} \cdot k_{b}{ }^{4} \eta^{4}\right. \\
\left.+(C-3)^{2} \cdot k_{s} \cdot k_{b}{ }^{2} \cdot \eta^{2}\right\}^{1 / 2}
\end{array}}{4 k_{b}{ }^{2} \eta^{2}+2(1-C) k_{s}{ }^{2}} \cdots(36)
$$

ここに, $\eta=\tau / \sigma_{C}$ である.

以上は弾性座屈に関するものである, 一方, 非弾性座 屈応力度は, 㛜密には, 同じ広さの塑性化が生じても, その位置などにより影響を受けると考えられる。しかし ながら, 本解析では実用的な極限強度解析を重視してい るので, 板の非弾性領域の座屈応力度の低下率が, 板の 弾性領域断面積の全断面積に対する比率に等しいと伙定 した。このような仮定に基づくと，板の平均的な剛性低 下率は式（37）で与えられる。な㧍，このような佂定を 設けて腹板の非弾性座屈応力度を求め, それを極限強度 解析に活用した解析值は, 後述の 図一10 および図一11 に示すように, 実験值とよく対応していることがわかっ た.このように帰納的ではあるが，プレートガーダーの 極限強度を算定する場合には, 式 (37) のような仮定は, 実用性の面ではあまり問題にはならないと考えられる.

$$
\bar{E} / E=\sum_{i=2} \Delta A / \underset{i=2}{\mathscr{Q}} \Delta A
$$


小松・森脇・藤野・滝本 :

このときの非弾性せん断座屈応力度 $\left({ }_{p} \tau_{c r}\right)$ およびそ のときのせん断力 $\left({ }_{p} Q_{c r}\right)$ および曲げモーメント $\left({ }_{p} M_{c r}\right)$ は次式で与えられる.

$$
\left.\begin{array}{l}
{ }_{p} \tau_{c r}=k_{s c} \cdot \sigma_{e} \cdot \sum_{i=2} \Delta A / \underset{i=2}{{ }_{p} \Delta A} \\
{ }_{p} Q_{c r}=k_{s c} \cdot \sigma_{e} \cdot \sum_{i=2} \Delta A \\
{ }_{p} M_{c r}={ }_{p} Q_{c r} \cdot L_{s}
\end{array}\right\}
$$

b）桁全体の水平座屈強度

桁全体が水平座屈に起因して崩壊するモードに対する 極限モーメントは，T.V. Galambos ${ }^{33)}$ に示されている 次式を活用する.

$$
\begin{aligned}
{ }_{L} M_{u}= & \pi\left\{E \cdot { } _ { e } I _ { y } \left(G \cdot{ }_{e} K_{T}+\bar{K}\right.\right. \\
& \left.+\pi^{2} \cdot E \cdot{ }_{e} I_{w} / L_{e}\right\}^{1 / 2} / L_{e}
\end{aligned}
$$

ここに, $L_{\boldsymbol{e}}$ は有効横構間隔を示す. また, $\bar{K}$ は弾性断 面から求められるせん断中心まわりの応力トルクであ り, 次式で与えられる.

$$
\bar{K}=\Phi\left[\left\{\left(y-e y_{s}\right)^{2}+x\right\} \cdot \sigma_{z} \cdot \Delta A\right]
$$

また, 桁全体が 水平座屈に起因して崩壊するときの極 限せん断力 $\left({ }_{L} Q_{u}\right)$ は, 曲げモーメントとせん断力の比 $\left(L_{s}\right)$ を用いて次式により与えられる.

$$
{ }_{L} Q_{u}={ }_{L} M_{u} / L_{s}
$$

c） T断面のねじれ座屈強度

桁全体がT断面のねじれ座屈に起因して崩壊するモー ドに対する極限圧縮軸力 $\left(P_{T}\right)$ は, T.V. Galambos ${ }^{33)}$ に示されている次式を活用する.ただし, 腹板の座屈し た領域は，T断面のねじれに抵抗しないものとする。

$$
\begin{aligned}
& P_{T}=-\left\{\left(R^{2}+4 y_{0}{ }^{2} \cdot R \cdot \pi^{2} \cdot E \cdot{ }_{e} I_{y T} / L_{e} T^{2}\right)^{1 / 2}\right. \\
& -R\} /\left(2 y_{0}^{2}\right)
\end{aligned}
$$

ここに， $R$ は次式で与えられる.

$$
R=\pi^{2} \cdot E \cdot{ }_{e} I_{w T} / L_{e} T^{2}+G \cdot{ }_{e} K_{T T}+\bar{K}_{T}
$$

また， $L_{e} T$ は $\mathrm{T}$ 断面のねじれに対する有効横構間隔 を示寸. また， $\bar{K}_{T}$ はせん断中心まわりの応力トルクを 意味し，次式で与えられる。

$$
\bar{K}_{T}={ }_{T} \Phi\left[\left\{\left(e y_{s T}-y\right)^{2}+x^{2}\right\} \cdot \sigma_{z} \cdot \Delta A\right]
$$

また, 式（42）の $y_{0}$ は, $\mathrm{T}$ 断面のせん断中心と重心 との距離を示し, 次式で求められる.

$$
y_{0}=T_{T}(\Delta A \cdot y) / T \& A-{ }_{e} y_{s} T
$$

いま，あるせん断力 $\left(Q_{0}\right)$ が作用したときの圧縮側 $\mathrm{T}$ 断面に作用する圧縮力 $\left(P_{0 T}\right)$ は次式で与えられる.

$$
P_{0 T}=T \&\left(\sigma_{z} \cdot \Delta A\right)
$$

一方, T断面のねじれ座屈が起こるのは, 次の不等式 が成立する場合である.

$$
P_{0 T} \leq P_{T}(<0)
$$

これらの軸力で表示した式をせん断力に変換して, $\mathrm{T}$ 断面のねじれ座屈荷重 $\left({ }_{T} Q_{u}\right)$ および座屈判定条件を次 式に示す.

$$
{ }_{T} Q_{u} / P_{T}=Q_{0} / P_{0 T}
$$

$$
Q_{0} \geq T Q_{u}
$$

なお, $P_{T}, P_{0 T}$ を算定するに必要な腹板の有効幅は

3. で述べる.

\section{d） せん断極限強度}

既報 ${ }^{14), 16)}$ の実験的研究で述べたように，せん断力が 支配的となって崩壊するモードは, 腹板のせん断座屈に よって生じた斜張力が限界に達し，そのまま崩壊するも のもあるが, その後, 上下フランジに塑性ヒンジを形成 して崩壊するものも認められた.

まず，斜張力の限界について一つの要素を取り出して 考えてみる. ある要素の腹板座屈までの応力（図-5 (a)）に，腹板座屈後の曲げモーメントによる $z$ 軸方向 の応力（図一5 (b) と斜張力（図一5 (c)）を重ね合わせ たものが, Mises の降伏条件を満たすとき，この要素の 斜張力が限界に達したものとし，この要素においてはそ の後の応力増加はないものとする. そして, 腹板の全要 素において，このように斜張力が限界值に達するときま での腹板座屈後のせん断力の増加量を, 斜張力場作用せ ん断力 $\left(Q_{t}\right)$ と称することにする. また，腹板の斜張力 が限界值に達した後は, 上下フランジに図一5 (d) に示 すような塑性ヒンジを形成するまでは, 若干の外力の増 加に対して抵抗し得るものとする.このときに負荷でき る耐荷余力を，枠組作用せん断力 $\left(Q_{f}\right)$ とよぶことにす る.この $Q_{f}$ の下限值は次式より得られる.

$$
Q_{f}=\frac{1}{a} \sum_{n=1}^{4} M_{p n}=\frac{2}{a}\left(M_{P U}+M_{P L}\right)
$$

ただし，
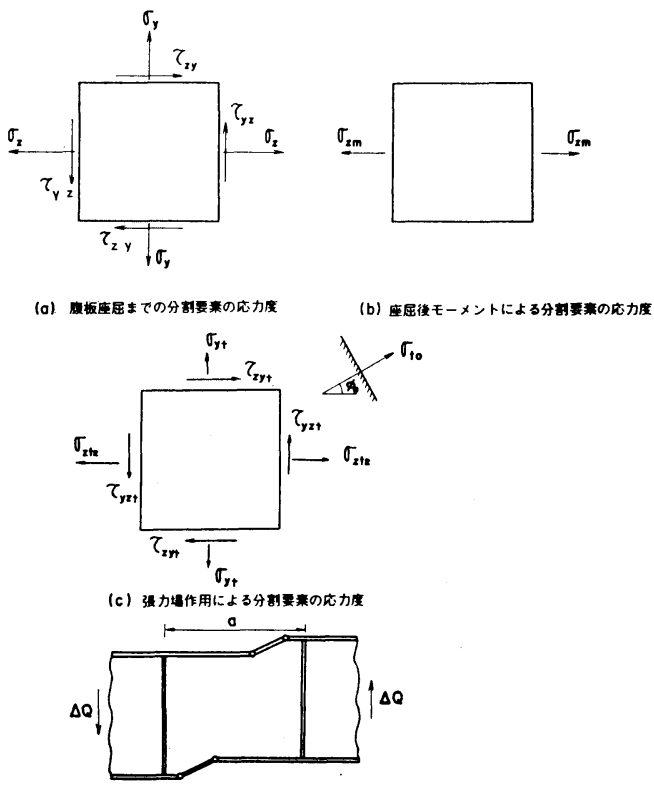

(d) 粗作用

図一5 せん断力下における座届, 崩壊モデル 


$$
\begin{aligned}
& M_{P U}=\frac{t_{f}}{2} \cdot \frac{\sum_{i=1}\left(\sigma_{y f}+\sigma_{z}\right) \cdot \sum_{i=1}\left\{\left(\sigma_{y f}-\sigma_{z}\right) \cdot \Delta A\right\}}{\sum_{i=1}\left(\sigma_{y f}+\sigma_{z}\right)+\sum_{i=1}\left(\sigma_{y f}-\sigma_{z}\right)} \\
& M_{P L}=\frac{t_{f}}{2} \cdot \frac{\sum_{i=3}\left(\sigma_{y f^{\prime}}+\sigma_{z}\right) \cdot \sum_{i=3}\left\{\left(\sigma_{y f^{\prime}}-\sigma_{z}\right) \cdot \Delta A\right\}}{\sum_{i=3}\left(\sigma_{y f^{\prime}}+\sigma_{z}\right)+\sum_{i=3}\left(\sigma_{y f}{ }^{\prime}-\sigma_{z}\right)}
\end{aligned}
$$

ここに， $\sigma_{z}$ は腹板の斜張力が限界に達したときのフラ ンジの 各分割要素に作用する軸応力度であり, $M_{P U}$ は, この軸応力度を考慮した上フランジの全塑性モーメ ントまでの耐荷余力モーメントである. 同様に $M_{P L}$ は， 下フランジの耐荷余力モーメントである. なお， $a$ は垂 直補剛材間隔である。 $\sigma_{y f}, \sigma_{y f^{\prime}}$ はそれぞれ上 フランジ，下フランジの降伏応力度である.

以上をまとめ, 桁の極限せん断力 $\left(Q_{u}\right)$ の近 似値は次式で与えられる.

$$
Q_{u}=Q_{c r}+Q_{t}+Q_{f}
$$

次に, 腹板座屈後の応力計算に大きな影響を 与える斜張力の傾斜角 ( $\phi$ ) は, Mises の降伏 条件を腹板全要素が満たし，かつそのときに， 斜張力の桁軸方向成分に抵抗する上下フランジ の限界強度が最大となるときの傾斜角を数值計 算によって決定した.

\section{3. フローチャートおよび適用経験式}

2.では，計算に必要な各事項ごとの 考え方 および定式化について述べたが，実際の数值解
析は, 図一6に示す基本フローチャートにより実施した. また, 計算に必要な残留応力分布および圧縮フランジに 協力する腹板の有効幅, さらに斜張力の平均化係数は, 次のように求めた．残留応力分布は，既報 ${ }^{14), 29)}$ の結果 と式（52）に示すつり合い条件式より，表一1 のように 求めた. ただし, 表一1 の残留応力分布は, 工程 1 （ガ ス切断によって板取りをする), 工程 2 (溶接によって 各部材を I 断面に組立てる), および工程 3 (スポット ヒーティングによってひずみ矯正をする）において，そ れぞれ異なったモードで発生することを示している. 最

表一1 残留応力分布の経験式 $\left(A_{Q}, G\right.$ タイプ)

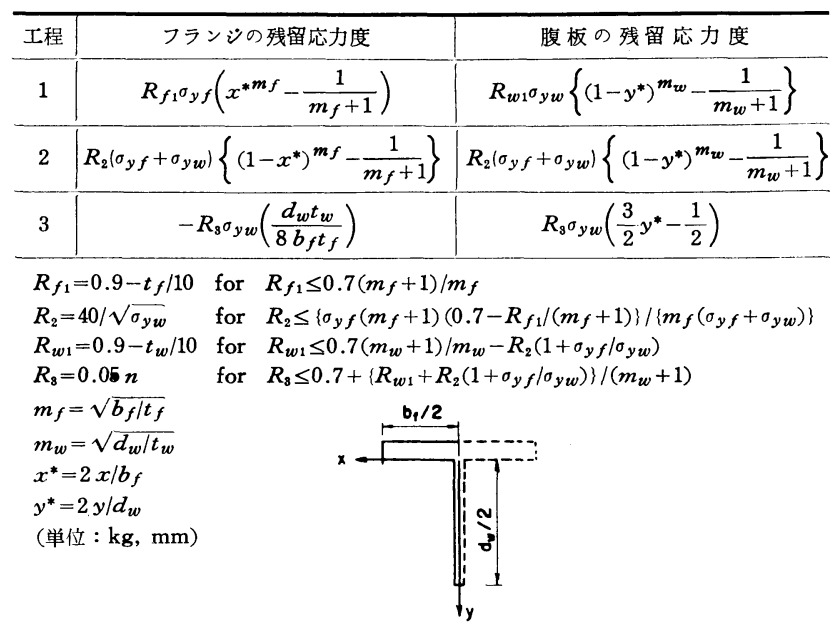
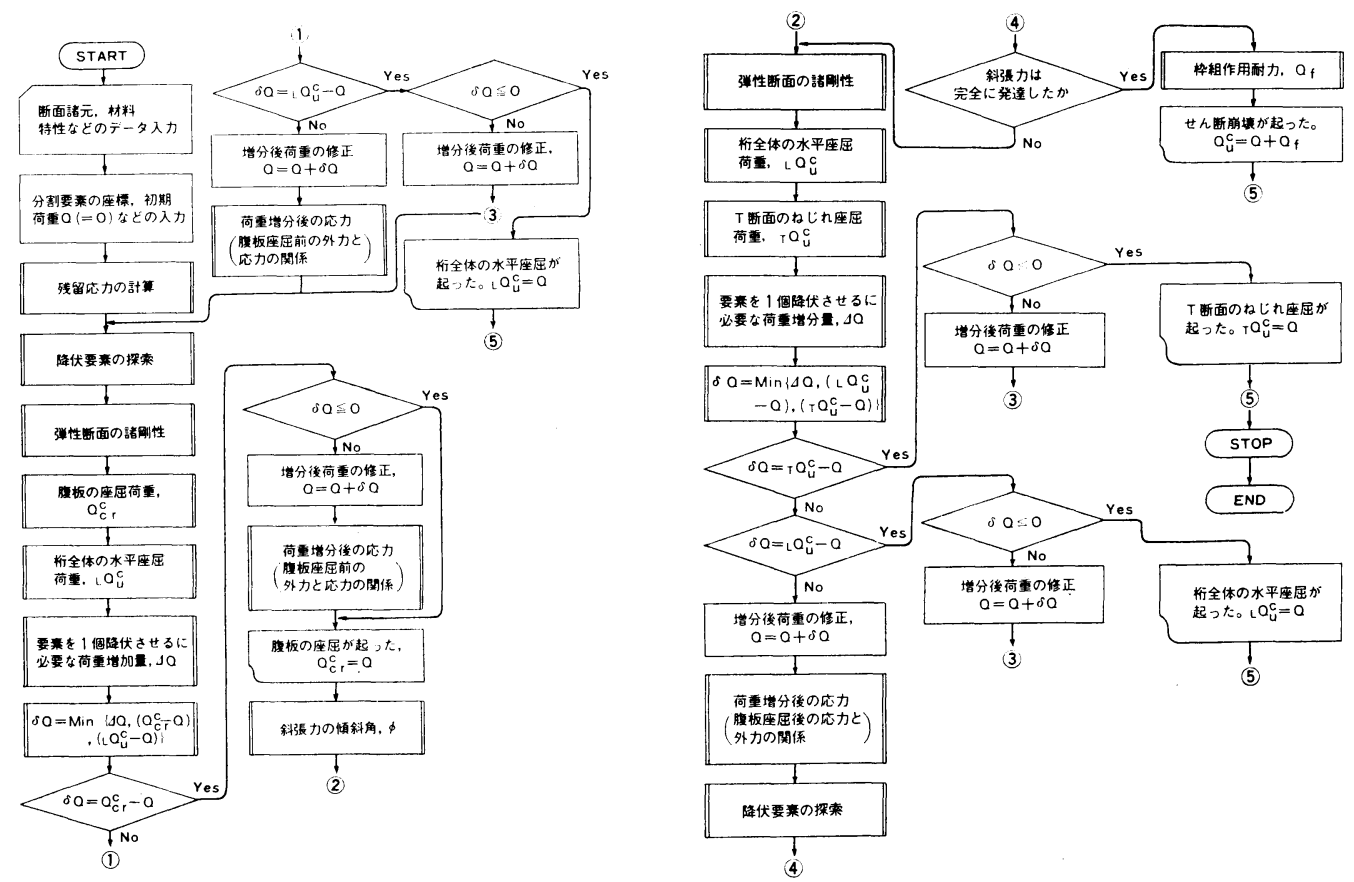
終的に発生する残留応力分布は，これら各工程で発生す る分布の和で与えられる. 同表に示した残留応力分布の 経験式は, 既報 ${ }^{14), 29}$ で示したように，60 キロ級高張力 鋼よりなる $A_{\mathrm{Q}}$ タイプ, および軟鋼よりなる $\mathrm{G}$ タイプ の供試体に適用可能である.

$$
\left.\begin{array}{l}
\int_{A} \sigma_{r z} \cdot d A=0 \\
\int_{A} \sigma_{r z} \cdot\left(y-y_{c}\right) d A=0
\end{array}\right\}
$$

ただし，

$\int_{A} d A:$ 桁の断面全体の面積分

$\sigma_{r z}: z$ 軸方向の残留応力度

$y_{c}:$ 全断面の図心の $y$ 座標

この 表一1に示した残留応力分布の経験式と実験 值 ${ }^{14), 29)}$ の比較を 図一7 に示す.これらの実験值と経験 式の相異は, 最大でも $5 \mathrm{~kg} / \mathrm{mm}^{2}(49 \mathrm{MPa})$ 以内に収ま るようである。

次に，圧縮側 $\mathrm{T}$ 断面の㸚じれ座屈強度に影響を及ぼす 有効幅 $\left(e_{w}\right)$ の実験值は, 文献 15) で得られた腹板の非
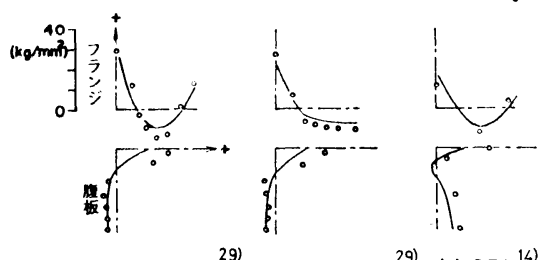

(c) $G R Y_{1}^{14}$
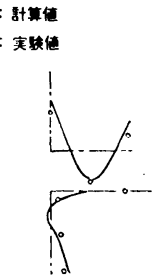

(d) $A_{0} R Y_{1}^{14)}$

図一7 残留応力に関する実験值と本経験式の比較 $\left(1 \mathrm{~kg} / \mathrm{mm}^{2}=9.8 \mathrm{MPa}\right)$

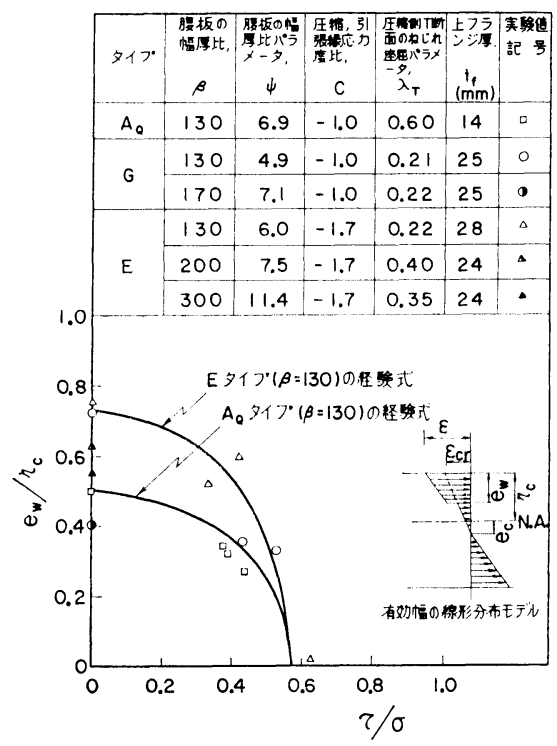

図一8 有効幅の実験値と経験式の比較

線形ひずみ分布を線形分布モデル（図一8 の付図）に置 き換え，それらのモーメントが同等であるといら条件よ り求めると, 図一8 の実験点のようになる. 同図より有 効幅の経験式 $\left(e_{w}^{e \cdot f}\right)$ は次式のように与えられる.

$$
\left(\frac{e_{w}{ }^{e \cdot f} / \eta_{c}}{A}\right)^{2}+\left(\frac{\tau / \sigma}{B}\right)^{2}=1
$$

ただし，

$$
\begin{aligned}
A= & -0.3 \lambda_{T}-(0.046 C+0.114) \phi \\
& +(0.19 C+1.33)
\end{aligned}
$$$$
B=1 / \sqrt{3}
$$

ここに, $\lambda_{T}$ は $\left(r_{0}^{3} \cdot P_{y f} / C_{f}\right)^{1 / 2}$ であり $, r_{0}, P_{y f}, C_{f}$ は， それぞれ圧縮フランジの断面 2 次半径, 降伏軸力, St. Venant のねじれ剛性である.11 個の供試体について本 経験式 $\left(e_{w}{ }^{e \cdot f}\right)$ と実験值 $\left(e_{w}{ }^{e}\right)$ の比 $\left(e_{w}{ }^{e} / e_{w}{ }^{e \cdot f}\right)$ の平 均は 0.998 , 標準偏差で, 0.117 となり若干ばらつきが 認められる。この場合, ねじれ座屈強度解析に及ぼす影 響は，95\% の確率で $2 \%$ 以内の誤差で解析可能である. したがって, この $e_{w}^{e \cdot f}$ の使用は工学的には十分実用 性があると考えられる.

次に，2.で述べた斜張力場作用せん断力 $\left(Q_{t}\right)$ に影 響を与える斜張力の平均化係数 $\rho$ は, 図一4 (b) に示 すように, 腹板全面の斜張力場に $0 \leq \rho \leq 1$ の範囲の 均一な不完全斜張力が生じているとした場合の $\rho=1$ (こ の場合は腹板全面が完全張力場の状態である）に対する 割合である. 本研究では, 実験で得られた各供試体の耐 荷力の值に最も近い解析值を算出する $\rho$ の值を， $0 \leq \rho$ $\leq 1$ の区間で数值実験により求めた. その結果， $\rho$ の経 験式は次式で与えられる.

$$
\rho=1 /\left(1+\alpha^{2 / 3}\right)
$$

\section{4. 解析値と実験値の比較}

以上の数值解析方法さらに，既報の経験式 ${ }^{14}$ 〜 16), $\operatorname{Herzog}^{12)}$ の提案式の妥当性を検証し，その適用範囲を 調查する目的で, 実験値 とこれらの解析值を比較 してみる. 実験値は, 図 一9に示す支持条件のも のに統一した. すなわ ち, 横倒れ防止板の配置 から，桁全体の横方向お よびねじれ変形に対し

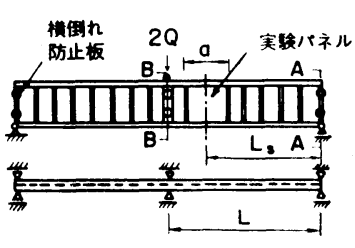

図一9載荷実験における 支持方法
て, A-A 断面で単純支持, B-B 断面で固定されたも のである.したがって, 水平座屈強度に影響を与える有 効横構間隔 $\left(L_{e}\right)$ は次式で与えられる.

$$
L_{e}=0.7 \mathrm{~L}
$$

そこで，これまで報告された供試体 74 体（文献 16）， 
18）２8））を対象として解析値と比較する.これらの供 試体は, $1.5 \leq \phi \leq 18.0,0.5 \leq \alpha \leq 3.7,0.12 \leq \tau / \sigma_{c}$ $\leq 3.75,-17 \leq C \leq-0.49,0.40 \leq \lambda_{c} \leq 4.44$ という 範囲にある.ただし， $\lambda_{c}$ は式 (56) に示すパラメーター である. これらの実験值 $\left(Q_{u}{ }^{e}\right)$ と本解析式による解析 值 $\left(Q_{u(1)}{ }^{c}\right.$ および $\left.Q_{u(2)}{ }^{c}\right)$ を比較すると, 図一10 およ び図一11のようになる. $Q_{u(1)}{ }^{c}$ は, 腹板の周辺条件を (1) 周辺単純支持として解析した座屈強度を極限強度計 算に適用した值であり， $Q_{u(2)}{ }^{c}$ は，腹板の周辺条件を (2) 非載荷辺固定, 載荷辺単純支持とした場合の解析值 である.これらの図より, 全般的にみると, $Q_{u(2)}{ }^{c}$ の方 が $Q_{u(1)}{ }^{c}$ より実験值を良好に評価している.さらに， 次式に示すような, 腹板座屈時の腹板縁部における塑性 化の程度を示すパラメーター $\left(\lambda_{c}\right)$ で検討してみる.

$$
\lambda_{c}=\left[\sigma_{y w} /\left\{\left(\sigma_{i, c r}\right)^{2}+3\left(\tau_{i, c r}\right)^{2}\right\}^{1 / 2}\right]^{1 / 2}
$$

ただし， $\sigma_{i, c r}, \tau_{i, c r}$ は, 組合せ荷重下で腹板が座屈す るときに共存する理想弾性曲げ座屈応力度, せん断座屈 応力度である.

本解析の結果, $\lambda_{c}$ が 0.9 以下で, 腹板座屈時に腹板 縁部の塑性化が相当進行していると考えられるものにつ いては, $Q_{u(1)}{ }^{c}$ の方が $Q_{u(2)}{ }^{c}$ より $Q_{u}{ }^{e}$ に近い傾向を 示している. $\lambda_{c}$ が 1.4 以上のものについては, $Q_{u(2)}{ }^{c}$ の方が $Q_{u(1)}{ }^{c}$ より $Q_{u}{ }^{e}$ に近い傾向を示している. 以上 の結果より, 腹板座屈時の腹板縁部の塑性化が大きいも
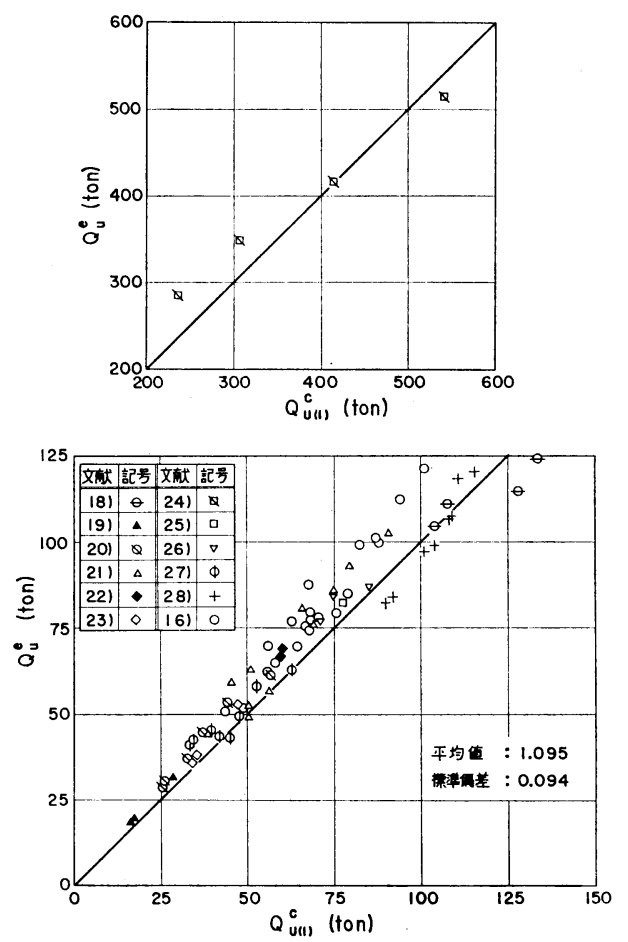

図一10 $\boldsymbol{Q}_{u}{ }^{e}$ と $\boldsymbol{Q}_{u(1)}{ }^{c}$ の比較 $(1 \mathrm{t}=9.8 \mathrm{kN})$
のほど, 周辺単純支持の腹板座屈強度を採用した桁全体 の極限強度に近いと評価される。このような理由によ り, $\lambda_{c}$ をパラメーターとして, 本解析值 $\left(Q_{u(1)}{ }^{c}, Q_{u(2)}{ }^{c}\right)$ をより実験值に近うけるための修正式 $\left(Q_{u(1)}{ }^{m}, Q_{u(2)}{ }^{m}\right)$ を最小二乗法により次式のように求めた.

$$
\begin{aligned}
& Q_{u(1)}{ }^{m}=\left(0.0283 \lambda_{c}+1.054\right) \cdot Q_{u(1)}{ }^{c} \ldots \\
& Q_{u(2)}{ }^{m}=\left(0.0174 \lambda_{c}+1.066\right) \cdot Q_{u(2)}{ }^{c} \ldots
\end{aligned}
$$

この $Q_{u(1)}{ }^{m}$ と $Q_{u}{ }^{e}$ の)関係を 図-12, $Q_{u(2)}{ }^{m}$ と $Q_{u}{ }^{e}$ の関係を 図一13 に示す. 実験值との優れた対応が涩め られる.

次に文献 14)，15）扩よび 16）で提示した次の強度経 験式 $\left(Q_{u}{ }^{e \cdot f}\right)$ と実験值 $\left(Q_{u}{ }^{e}\right)$ を比較すると図一14の ようになる。

$Q / Q_{u 0}^{e \cdot f}>\left\{1-0.145\left(M_{u 0}^{e \cdot f} / M_{y f}\right)\right\} /\left(M_{u 0}^{e \cdot f} / M\right)$ でせん断崩壊モードの場合,

$$
\begin{aligned}
Q_{u}{ }^{e \cdot f} / Q_{p}= & \left\{\left(Q_{u 0}^{e \cdot f} / Q_{p}\right)\right\} / \\
& \left\{1+0.145\left(M / M_{y f}\right) /\left(Q / Q_{u}{ }^{e \cdot f}\right)\right\}
\end{aligned}
$$

$Q / Q_{u 0}^{e \cdot f} \leq\left\{1-0.145\left(M_{u 0}^{e \cdot f} / M_{y f}\right)\right\} /\left(M_{u 0}^{e \cdot f} / M\right)$ で曲げ崩壊モードの場合,

$$
M_{u}^{e \cdot f} / M_{y f}=M_{u 0}^{e \cdot f} / M_{y f}
$$

ただし, $Q_{u 0}^{e \cdot f}, M_{u 0}^{e \cdot f}$ はそれぞれ純せん断力下にお ける桁全体の極限強度, 純曲げモーメント下における桁 全体の極限強度で, 以下に示される.
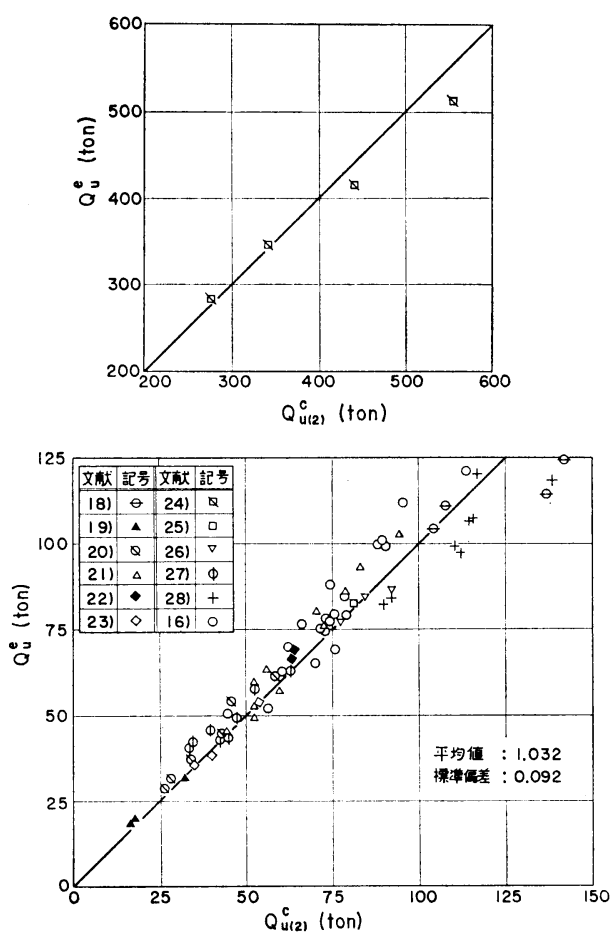

図一11 $\boldsymbol{Q}_{u}^{e}$ と $\boldsymbol{Q}_{u(2)}{ }^{c}$ の比較 $(1 \mathrm{t}=9.8 \mathrm{kN})$ 

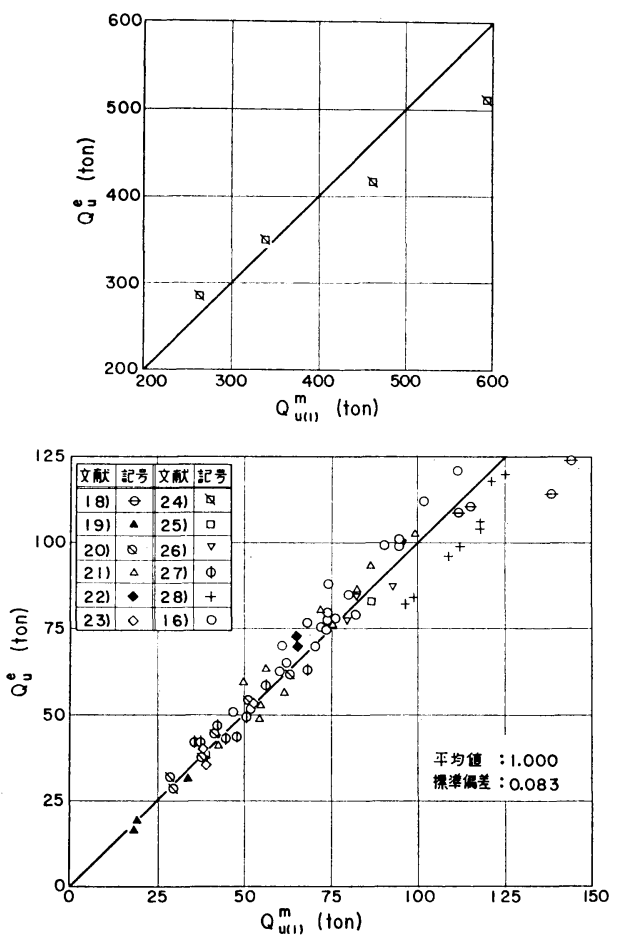

図-12 $\boldsymbol{Q}_{u}{ }^{e}$ と $\boldsymbol{Q}_{u(1)}{ }^{m}$ の比較 $(1 \mathrm{t}=9.8 \mathrm{kN})$

$Q_{u 0}^{e \cdot f} / Q_{p}=\alpha^{-0.4} \cdot(2.0 / \phi+0.53)$

$M_{u 0}^{e \cdot f} / M_{y f}=M_{i n} \cdot\left\{{ }_{L} M_{u 0} e \cdot f / M_{y f}\right.$,

$$
\left.{ }_{T} M_{u 0} e \cdot f / M_{y f}\right\} \text {. }
$$

ここに, ${ }_{L} M_{u 0}{ }^{e \cdot f}$ および $T_{T} M_{u 0} e \cdot f$ はそれぞれ純曲げモ 一メント下でフランジの水平座屈に起因して桁が崩壊す る場合の極限モーメント，およびねじれ座屈に起因して 桁が崩壊する場合の極限モーメントであり，次式のよう に示される. なお， $M_{y f}$ は，圧縮フランジ縁が降伏す るときの曲げモーメントである。

(1) 水平座屈に起因する極限強度 :

\section{$1.22<\lambda_{L}$ の場合}

$$
\begin{aligned}
{ }_{L} M_{u 0} e \cdot f / M_{y f}= & {[2.42+\{5.85-9.86(0.62} \\
& \left.\left.\left.-1 / \lambda_{L}{ }^{2}\right)\right\}^{1 / 2}\right] / 4.93 \cdots \cdots \cdots
\end{aligned}
$$

$0.50<\lambda_{L} \leq 1.22$ の場合

$$
{ }_{L} M_{u 0} e \cdot f / M_{y f}=0.085 / \lambda_{L}{ }^{2}+0.95 \text {. }
$$

ここに, $\lambda_{L}=\left(L^{2} \cdot P_{y f} / B_{f}\right)^{1 / 2}$ であり, $L$ は横構間隔, $P_{y f}, B_{f}$ はそれぞれ圧縮フランジの降伏軸力および, 水平曲げ剛性である.

(2) ねじれ座屈に起因する極限強度 :

$0.48<\lambda_{T}$ の場合

$$
\begin{aligned}
& { }_{T} M_{u 0}{ }^{e \cdot f} / M_{y f}=[12+\{145-52(3.3 \\
& \left.\left.\left.-1 / \lambda_{T^{2}}\right)\right\}^{1 / 2}\right] / 26
\end{aligned}
$$

$0.35<\lambda_{T} \leq 0.48$ の場合

$$
{ }_{T} M_{u 0}{ }^{e \cdot f} / M_{y f}=0.040 / \lambda_{T}{ }^{2}+0.82
$$
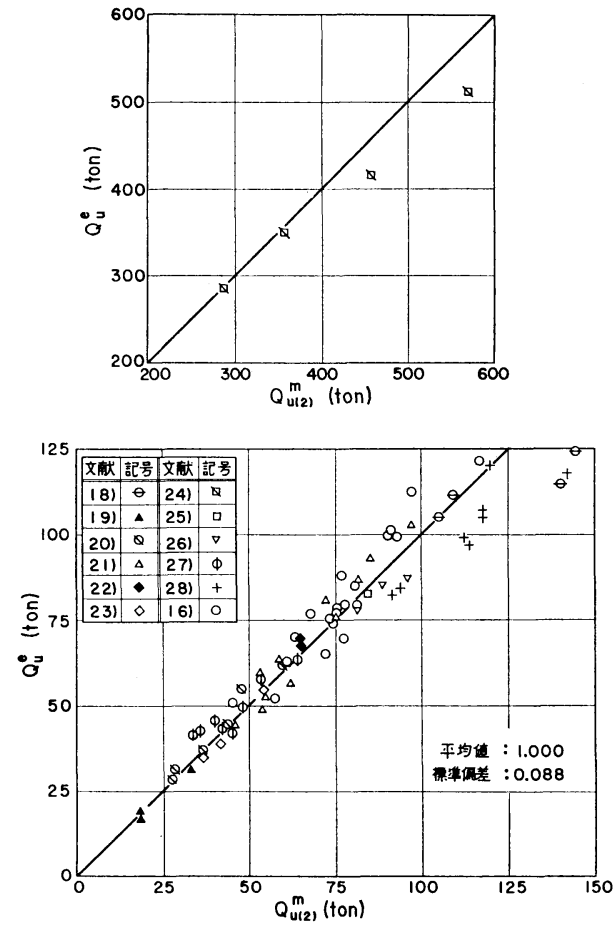

図一13 $\boldsymbol{Q}_{u}{ }^{e}$ と $\boldsymbol{Q}_{u(2)}{ }^{m}$ の比較 $(1 \mathrm{t}=9.8 \mathrm{kN})$
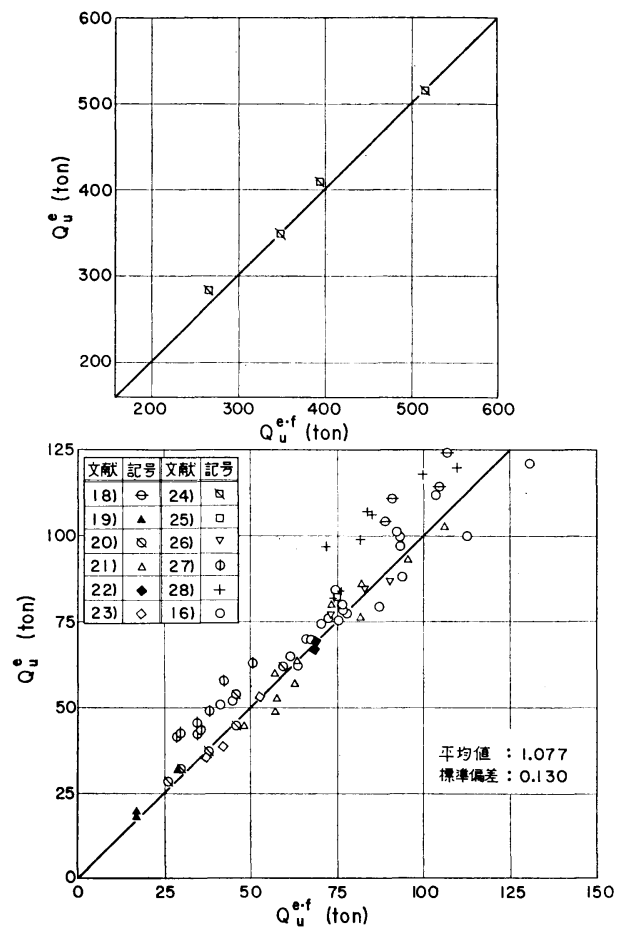

図-14 $\boldsymbol{Q}_{u}{ }^{e}$ と $\boldsymbol{Q}_{u}{ }^{e \cdot f}$ の比較 $(1 \mathrm{t}=9.8 \mathrm{kN})$

ここに, $\lambda_{T}=\left(r_{0}{ }^{2} \cdot P_{y f} / C_{f}\right)^{1 / 2}$ で, $r_{0}$ および $C_{f}$ は，そ れぞれ圧縮 フランジの断面 2 次半径および St. Venant 

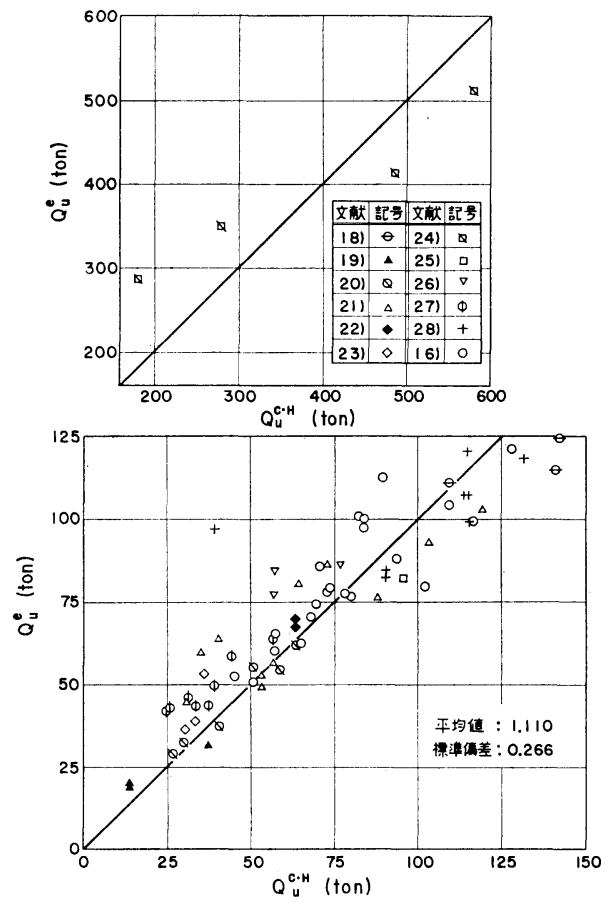

図一15 $\boldsymbol{Q}_{u}{ }^{e}$ と $\boldsymbol{Q}_{u}{ }^{c . H}$ の比較 $(1 \mathrm{t}=9.8 \mathrm{kN})$

のねじれ剛性である.

次に, Herzog ${ }^{12)}$ の提案式による $Q_{u}{ }^{c \cdot H}$ と実験值 $\left(Q_{u}{ }^{e}\right)$ の関係を 図一15 に示す. かなりの偏差が認めら れる.

図一10 15 を比較すると, $Q_{u(1)}{ }^{m}$ と $Q_{u(2)}{ }^{m}$ が実験 值と最もよく一致し, $Q_{u(2)}{ }^{c}, Q_{u(1)}{ }^{c}, Q_{u}{ }^{e \cdot f}, Q_{u}{ }^{c \cdot H}$ の 順となる.また，これらの図の中で示されている参考文 献に掲げた供試体の諸元から判断すると，10\% の誤差 以内で実験值を評価できる適用範囲は, 本解析法による $Q_{u(1)}{ }^{m}, Q_{u(2)}{ }^{m}, Q_{u(1)}{ }^{c}$ および $Q_{u(2)}{ }^{c}$ の場合には, 3.5 $\leq \psi \leq 18.0,0.5 \leq \alpha \leq 3.7$ といらきわめて広範囲の 垂直補剛材付き溶接プレートガーダーに適用可能であ る. 同様に, 著者らの先に提案した強度経験式 $\left(Q_{u}{ }^{e \cdot f}\right)$ は, $3.5 \leq \psi \leq 18.0,0.5 \leq \alpha \leq 2.5$ の範囲で, $10 \%$ の 誤差で実験値を評価可能であり, 本解析式より $\alpha$ 範囲 がわずかに小さくなっているものの, 通常の溶接プレー トガーダーには十分適用可能と考えられる. 最後に, Herzog の提案式 $\left(Q_{u}{ }^{c \cdot H}\right)$ の適用範囲は, 実験值を 10 $\%$ 以内で評価できる場合に限ると, $4.0 \leq \psi \leq 6.4,0.5$ $\leq \alpha \leq 1.0$ となり, 前述の本解析式㧍よび強度経験式 に比較して，その適用範囲がきわめて小さいことが明ら かとなった。

次に, 本解析によって各種因子の影響について, $\mathrm{A}_{\mathrm{Q}} \mathrm{CY}_{1}-4$-(2)の供試体 $(\beta=130, \phi=6.42, \alpha=1.0, C=$ $-1.0, \tau / \sigma_{c}=0.38$, スポットヒーティングあり, $\sigma_{y w}=$

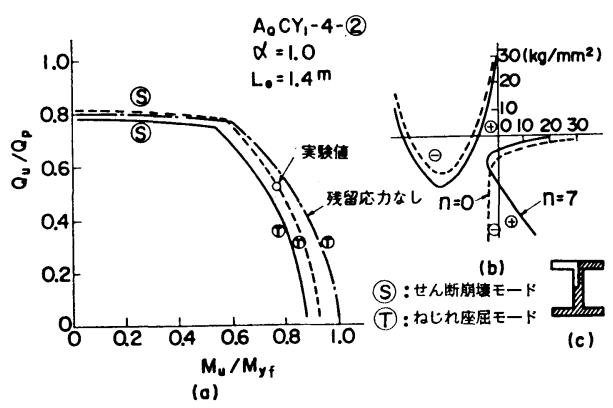

図一16 残留応力が組合せ極限強度に及ぼす影響 $\left(1 \mathrm{~kg} / \mathrm{mm}^{2}=9.8 \mathrm{MPa}\right)$

$\left.53 \mathrm{~kg} / \mathrm{mm}^{2}(519 \mathrm{MPa}), \sigma_{y f}=56 \mathrm{~kg} / \mathrm{mm}^{2}(549 \mathrm{MPa})\right)$ を 例にして述べる.

\section{（1）残留応力が桁全体の極限強度に及ぼす影響}

$\mathrm{A}_{\mathrm{Q}} \mathrm{CY} \mathrm{Y}_{1}$-4-(2) は，既報 ${ }^{16)}$ で述べたように，ひずみ矯正 のために腹板にスポットヒーティングが施されており， 腹板中央断面でのその個数 $(n)$ は 7 であり, 断面の残 留応力分布は, 図一16 (c) に示す白地のように断面の 1/4 を取り出すと，同図（b）の実線のようになるが, このときの相関曲線は同図（a）の実線のようになる. また，○印は実験值である．次に，仮にスポットヒーテ イングが施されなかったとすると $(n=0)$, 残留応力分 布は同図 (b) の破線のようになり，相関曲線は同図 (a) の破線のようになる.これらを比較すると， $n=0$ の場 合はすべての領域で, $n=7$ の場合に比較して, 極限強 度が 3\%〜5\% と若干ではあるが増加する. 次に, 残留 応力がまったく生じていないような I 断面を想定し，そ の相関曲線を求めてみると, 同図（a）の鎖線のように なり, 曲げが支配的な場合の $M_{u} / M_{y f}$ が他のものより 若干大きくなる.このように, 通常の垂直補剛材のみを 有する溶接プレートガーダー全体の極限強度は, 残留圧 縮応力度の影響を若干受ける傾向が認められる. しかも その傾向は, 曲げモーメントの大きい領域で強く現われ る.また，腹板に扔けるスポットヒーティングを極端に 多くして, 圧縮フランジの残留圧縮応力度を大きくする と，極限強度が低下する傾向が現われる。

\section{（2）垂直補剛材間隔が桁全体の極限強度に及ぼす影 響}

図-17 は, $\mathrm{A}_{\mathrm{Q}} \mathrm{CY}_{1}$-4-(2) の供試体について, 垂直補 剛材間隔を腹板高さの 0.5 倍, 1.0 倍, 1.5 倍, 2.0 倍 とした場合のおのおのについて相関曲線を示したもので ある. 同図より，せん断力が支配的な領域において，桁 全体の極限強度に垂直補剛材間隔が大きな影響を与える ことがわかる.しかも， $\alpha$ が大きくなるにつれて極限強 度は低下する。 


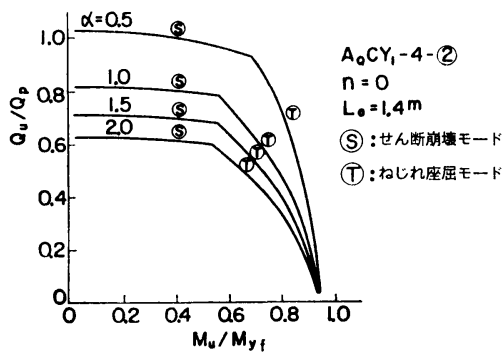

図-17 腹板パネル縦横比が組合せ極限強度 に及ぼす影響

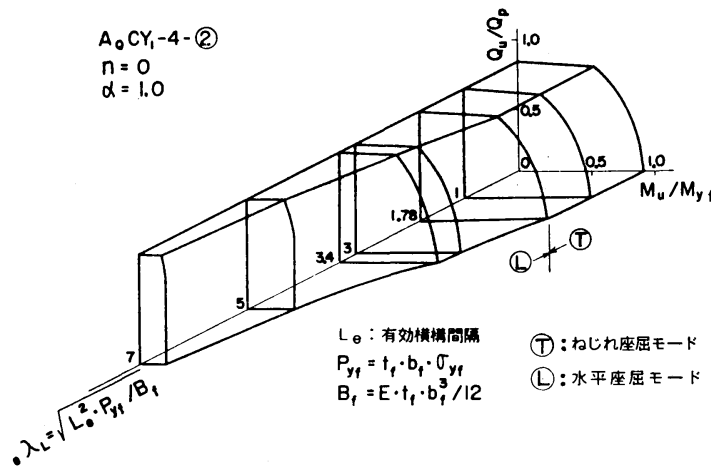

\section{図一18横構間隔が組合せ極限強度に及ぼす影響}

\section{（3）有効横構間隔が标全体の極限強度に及ぼす影響}

図一18 は， $\mathrm{A}_{\mathrm{Q}} \mathrm{CY}_{1}$-4-(2) の供試体について，有効横 構間隔 $\left(L_{e}\right)$ に比例する無次元量 $\left({ }_{e} \lambda_{L}\right)$ を, 相関曲線の 両軸と直交する軸にとって示したものである．この図か ら， $e^{\lambda_{L}} \leq 1.78$ の範囲では，曲げモーメントの支配的 な領域は，ねじれ座屈によって桁全体の極限強度が支配 され，この籁囲では， $L_{e}$ は極限強度に影響を及ぼさな い.また， $1.78<{ }_{e} \lambda_{L} \leq 3.4$ の範囲では，曲げが支配 的な領域の極限強度は，非弾性水平座屈によって決定さ れる. また, $e^{\lambda_{L}}>3.4$ の領域では，桁全体の弾性的な 水平座屈によって，桁全体の極限強度が決まると考えら れる。

\section{（4）圧縮フランジの幅厚比が桁全体の極限強度に及 ぼす影響}

図一19 は， $\mathrm{A}_{\mathrm{Q}} \mathrm{CY}_{1}$-4-(2) の供試体について，圧縮フ ランジの断面積を一定として, 板厚 $\left(t_{f}\right)$ を $10,12,14$, $16,18,20 \mathrm{~mm}$ と変化させたときの相関曲線を示したも のである. 同図より, $t_{f}=16 \mathrm{~mm}$ とした場合が最も大き な極限強度を有していることがわかる。

\section{（5）腹板の幅厚比が桁全体の極限強度に及ぼす影響}

図-20 は， $\mathrm{A}_{\mathrm{Q}} \mathrm{CY}_{1}-4$-(2) の供試体について, 腹板の 断面積を一定として, 腹板厚 $\left(t_{w}\right)$ を $4,5,6,7,8,9$

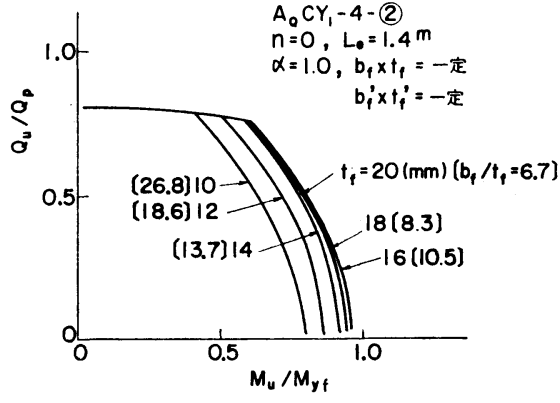

图一19 圧縮フランジの幅厚比が組合せ 極限強度に及ぼす影概

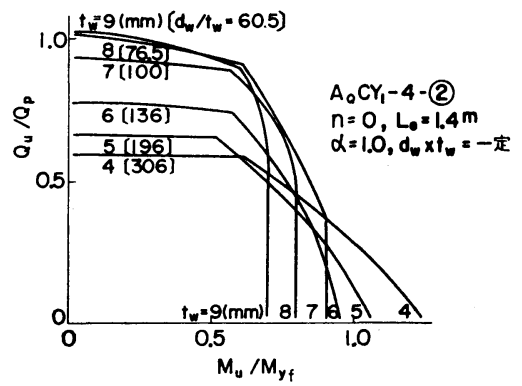

図一20 腹板の幅厚比が組合せ極限強度に及ぼす影響

$\mathrm{mm}$ と変化させたときの桁全体の極限強度を相関曲線で 示したものである.この図より，純曲げモーメントに近 、領域では, $t_{w}$ が小さいほど, また, 幅厚比 $(\beta)$ が大 きいほど, $M_{u} / M_{y f}$ は大きくなる傾向が顕著に認めら れる.一方，せん断力が支配的な領域では， $t_{w}$ が大きく なるにつれて， $Q_{u} / Q_{p}$ も増大する傾向があるが， $t_{w}=$ $9 \mathrm{~mm}$ の $Q_{u} / Q_{p}$ と $t_{w}=8 \mathrm{~mm}$ のそれとでは大差なく, これ以上大きくしても， $Q_{u} / Q_{p}$ はあまり増大しない傾 向を示している.

\section{5. あとがき}

曲げモーメントとせん断力が同時に作用するプレート ガーダー全体の極限強度について, 塑性解析を行いその 妥当性，ならびに著者らが先に提案した極限強度経験 式14) 16)の適用範囲について検討した結果, 以下のこと が明らかとなった。

（1）桁全体の極限強度に関して, 実験值 $\left(Q_{u}{ }^{e}\right)$ と 本解析式 $\left(Q_{u(1)}{ }^{c}, Q_{u(2)}{ }^{c}\right)$, 本解析の修正式 $\left(Q_{u(1)}{ }^{m}\right.$, $\left.Q_{u(2)}{ }^{m}\right)$, 既報 $\left.{ }^{14)} \sim 16\right)$ の経験式 $\left(Q_{u}{ }^{e \cdot f}\right)$ および Herzog ${ }^{12)}$ の提案式 $\left(Q_{u}{ }^{c \cdot H}\right)$ を比較した. その結果, 修正式が実 験值を最も精度よく評価し, 続いて, 本解析式, 経験 式, Herzog の提案式の順となる.

(2) 既報 ${ }^{14)}{ }^{16)}$ の経験式と 実験值の比 $\left(Q_{u}{ }^{e} / Q_{u^{e}}{ }^{e \cdot f}\right)$ の平均值 $(\bar{x})$ は 1.077 , 標準偏差 $\left(\sigma^{*}\right)$ は 0.130 であ 
り, $Q_{u}{ }^{e} / Q_{u(2)}{ }^{c}$ に比較して若干精度は劣るが, Herzog の $Q_{u}{ }^{e} / Q_{u}{ }^{c \cdot H}$ よりはるかに実験值とよく適合している. また実験值を $10 \%$ 以内で評価し得る範囲は，Herzog の 提案式の場合， $4.0 \leq \phi \leq 6.4,0.5 \leq \alpha \leq 1.0$ とかな り狭い範囲の限られたプレートガーダーにしか活用でき

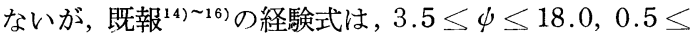
$\alpha \leq 2.5$, 本解析式およびその修正式は， $3.5 \leq \psi \leq$ $18.0,0.5 \leq \alpha \leq 3.7$ と，いずれも，かなり広範囲で活 用可能であり，一般の垂直補剛材を有する溶接プレート ガーダーに十分適用可能であって，その実用性が証明さ れた.

（3）代表的な解析モデルを取り上げ，桁全体の極限 強度を支配する重要な因子である残留応力, 垂直補剛材 間隔, 有効横構間隔, 圧縮フランジの幅厚比, および腹 板の幅厚比などが桁全体の極限強度に及ぼす影響につい て論じた.

\section{参 考 文 献}

1) Johnston, B.G. (ed.) : Guide to Stability Design Criteria Metal Structures, 3rd. ed., Structural Stability Research Council, John Wiley \& Sons, New York, 1976.

2) Klöppel, K. and J.S. Scheer : Beulwerte Ausgesteifter Rechteckplatten, Wilhelm Ernst \& Sohn, Berlin, 1960.

3) Basler, K. : Strength of Plate Girders in Shear, Proc. of ASCE, ST7, Vol. 87, Oct., 1961.

4) Basler, K. and B. Thürlimann : Strength of Plate Girders in Bending, Proc. of ASCE, ST 6, Vol. 87, Aug., 1961.

5) Basler, K. : Strength of Plate Girders under Combined Bending and Shear, Proc. of ASCE, ST 7, Vol. 87, Oct., 1961.

6) Ostapenko, A. and C. Chern : Ultimate Strength of Plate Girders under Shear, Fritz Eng. Laboratory Report No. 328.7 Lehigh Univ. Aug., 1969.

7) Ostapenko, A. and C. Chern : Bending Strength of Unsymmetrical Plate Girders, Fritz Eng. Laboratory Report No. 328.8, Lehigh Univ. Sept., 1970.

8) Ostapenko, A. and C. Chern : Unsymmetrical Plate Girders under Shear and Moment, Fritz Eng. Laboratory Report No. 328.9 Lehigh Univ., Oct., 1970.

9）秋田好雄・藤井登喜男：座屈と塑性を考慮した最小重量 設計一第 1 報・ガーダーのせん断座屈をともなら塑性崩 壊荷重一，造船協会論文集，No. 119，1966-6.

10）秋田好雄・藤井登喜雄 ：座屈と塑性を考虑した最小重量 設計一第 2 報・ウェブの曲げおよびせん断座屈をともな 5ガーダーの崩壊荷重一, 造船協会論文集, No. 120, 1966-12.

11) Fujii, T. : Minimum Weight Design of Structures Based on Buckling Strength and Plastic Collapse3rd Report.An Improved Theory on Post-Buckling Strength of Plate Girders in Shear一，造船協会論文集， No. 122, 1967-12.

12) Herzog, M. : Ultimate Static Strength of Plate Girders from Tests, Proc. of ASCE, ST 5, 1974-5.

13) Rockey, K.C. and M. Skaloud : The Ultimate Behaviour of Plate Girders Loaded in Shear, Structural Engineer, Vol. 50, No. 1, Jan., 1972.
14）森脇良一・藤野真之：初期不整を有するプレートガーダ 一のせん断強度に関する 実験的研究, 土木学会論文報告 集, 第 249 号, 1976-5.

15）森脇良一・藤野真之：初期不整を有するプレートガーダ 一の純曲げ強度に関する 実験的研究, 土木学会論文報告 集, 第 264 号, 1977-8.

16）藤野真之：初期不整を有するプレートガーダーの組合せ 強度に関する実験的研究，土木学会論文報告集，第 269 号, 1978-1.

17）小松定夫・森脇良一・藤野真之：初期不整を考慮したプ レートガーダーの強度設計に関する研究, 土木学会論文 報告集，第 272 号，1978-4。

18) Nishino, F. and T. Okumura : Experimental Investigation of Strength of Plate Girders in Shear, IABSE Theme II c, New York, 1968-9.

19) Dimitri, J.R. and A. Ostapenko : Pilot Tests on The Ultimate Static Strength of Unsymmetrical Plate Girders, Frits Eng. Laboratory Report No. 328.5 Lehigh Univ., June, 1968.

20) Schueller, W. and A. Ostapenko: Main Tests on The Ultimate Static Strength of Unsymmetrical Plate Girders, Fritz Eng. Laboratory Report No. 328.6 Lehigh Univ., Aug., 1968.

21) Lew, H.S. and A.A. Toprac: The Static Strength of Hybrid Plate Girders, Report No. S.F.R.L. RPT. P 550-11, The Univ. of Texas, Jan., 1968.

22) Fielding, D.J. and A.A. Toprac: Fatigue Tests of Hybrid Plate Girders under Combined Bending and Shear, Research Report No. 96-2, Center for Highway Research, The Univ. of Texas, July, 1967.

23) Basler, K., B.T. Yen, J.A. Mueller and B. Thürlimann : Web Buckling Tests on Welded Plate Girders, Bulletin No. 63, Welding Research Council, Sept., 1963.

24) Cooper, P.B., H.S. Lew and B.T. Yen : Welded Constructional Alloy Steel Plate Girders, Proc. of ASCE, Vol. 90, ST 11, Feb., 1964.

25) Cooper, P.B. : Bending and Shear Strength of Longitudinally Stiffened Plate Girders, Ph.D. Dissertation, Lehigh Univ., 1965.

26) Patterson, P.J. and B.T. Yen : Proof Tests of Two Plate Girders for Design Recommendation, Fritz Eng. Laboratory Report No. 327.7, Lehigh Univ., June, 1969.

27) Lyse, I. and H.J. Godfrey : Investigation of Web Buckling in Steel Beams, Trans. ASCE, Vol. 100, 1935.

28) Sakai, F., F. Nishino and T. Okumura : Failure Tests on Plate Girders, Structural Eng. Laboratory Report, Department of Civil Eng., Univ. of Tokyo, 1967.

29) Nagarajarao, N.R., F.R. Estuar and L. Tall : Residual Stress in Welded Shapes, The Welding Journal Res. Suppl., Vol. 43, 1964-7.

30) Komatsu, S. : Ultimate Strength of Stiffened Plate Girders Subjected to Shear, Proc. of Colloquium of Design of Plate and Box Girders for Ultimate Strength, IABSE Report, Vol. 11, Mar., 1971.

31) Maeda, Y. : Ultimate Static Strength and Fatigue of Longitudinally Stiffened Plate Girders in Bending, Proc. of Colloquium on Design of Plate and Box Girders for Ultimate Strength, IABSE Report, Vol. 11, Mar., 1971 
32) Chwalla, E. : Beitrag zur Stabilitätstheorie des Stegbleches vollwandiger Träger, Stahlbau, Vol. 9, 1936.

33） Galambos, T.V. 著 (福本唀士, 西野文雄共訳) : 鋼構造 部材と骨組一一強度と設計一一, 丸善, 1970.

34）長谷川彰夫・和田耕造・西野文雄：プレートガーダーの 曲げ耐荷力に関寸る 新しい理論, 土木学会論文報告集, 第 300 号, 1980-8.

35）福本唀士・藤原 稔・渡辺信夫：溶接 I 形部材の横倒れ 座屈に関する実験的研究，土木学会論文報告集，第 189
号, 1971-5.

36）長谷川彰夫・西野文雄・奥村敏恵：水平補剛材を有する プレート・ガーダーの曲げ耐荷力実験, 土木学会論文報 告集, 第 234 号, 1975-2.

37）長谷川彰夫・西野文雄・奥村敏恵：水平補剛材を有する プレート・ガーダーのせん断耐荷力, 土木学会論文報告 集, 第 235 号, 1975-3.

(1981.1.30 - 受付) 